\title{
RESEARCH AND EVALUATION OF RUTS IN THE ASPHALT PAVEMENT ON LITHUANIAN HIGHWAYS
}

\author{
Henrikas SIVILEVIČIUS, Vidmantas VANSAUSKAS \\ Department of Transport Technological Equipment, Vilnius Gediminas Technical University, Plytinès g. 27, \\ LT-10105 Vilnius, Lithuania
}

Received 1 Sep. 2012; accepted 8 Apr. 2013

\begin{abstract}
When exposed to destructive climate and weather factors and heavy vehicle loads, the pavement wears and deflects. In recent decades, apart from cracks and potholes, the depth of ruts grows and makes an increasing share of the pavement surface. The deeper are the tracks, the poorer are traffic conditions for fast-moving cars: drivers are struggling, speed is decreasing and the number of accidents is increasing. After track depth reaches a critical and permissible limit, the road surface must be repaired or speed limit has to be reduced. The work presents a theoretical analysis of track emergence causes and factors determining their depth. With the help of Mobile Road Research Laboratory RST 28, the track depth of all Lithuanian highways has been measured every 20 metres. The obtained data have been processed using the methods of mathematical statistics. Each road has a sample average of every rut, sample standard deviation and a coefficient of individually measured variation. The paper has drawn histograms, calculated skewness, kurtosis and normal distribution and provided lognormal distribution curves of a probability density function. The visualisation and empirical skewness and kurtosis values have revealed that the depth of the rut distributes according to lognormal rather than normal distribution. The average values of the roads having a dividing strip and standard deviations from the distribution across the road have been received. The given dependence of the rut depth of a standard deviation on the averages of rut depth shows an elastic interface of these parameters (determination coefficient $R^{2}=0.741$ ).
\end{abstract}

Keywords: asphalt pavement; rutting; in situ measuring; statistical analysis; depth distribution; skewness; kurtosis.

Reference to this paper should be made as follows: Sivilevičius, H.; Vansauskas, V. 2013. Research and evaluation of ruts in the asphalt pavement on Lithuanian highways, Journal of Civil Engineering and Management 19(5): 609-621. http://dx.doi.org/10.3846/13923730.2013.817481

\section{Introduction}

During the last decades, there have been dramatic changes in traffic volumes, traffic weights and tyre pressures, which have resulted in a significant increase in a permanent deformation of hot mix asphalt (HMA) pavements. Permanent deformation is a major mode of failure in flexible pavements consisting of both rutting and shoving (Hajj et al. 2011a).

Evaluation methods and tools used for assessing pavement conditions provide an invaluable service to infrastructure engineers, technicians, budget planners and decision makers. These tools provide information relevant to the maintenance and rehabilitation of national infrastructure (Thodesen et al. 2012).

According to ASTM E 867-02a (2004), a rut is a contiguous longitudinal depression deviating from a surface plane defined by a transverse cross slope and longitudinal profile. Rut depth is the maximum measured perpendicular distance between the bottom surface of the straightedge and the contact area of the gauge with the pavement surface at a specific location.

As time passes, pavement sections start deteriorating due to traffic and environmental effects (Haryanto, Takahashi 2007; Hu et al. 2011; Sivilevičius, Šukevičius 2007; Xia, Wang 2010; Wang et al. 2009; Yavuzturk et al. 2005; Petkevičius et al. 2010; AlSuleiman et al. 2000; Sivilevičius 2011a; Chandra 2004; Yang et al. 2009; Zhang et al. 2002; Xia 2010).

Road surface profile is an important factor that affects dynamic responses of the vehicle, which in turn affects pavement responses (Wang et al. 2012). The study has developed a complete two-dimensional axle-tyre-pavement interaction finite-element model to investigate the effects of the rutted surface on nearsurface pavement responses.

In general, pavement sections subjected to higher traffic volumes have a higher rate of deterioration. Consequently, thicker pavements with higher-quality 
materials are required for high traffic facilities (Zaghloul, Holland 2008). Therefore, it is not possible to compare the structural capacity of two pavement sections such as high traffic main interstate highways and low-traffic rural roads subjected to different traffic intensity without taking into consideration traffic effects.

Pavement surface deflections have been successfully used as an indicator of airport pavement life (Gopalakrishnan 2008). In this study, pavement surface deflections measured prior to trafficking have been related to the rutting performance of four flexible pavement test sections at the FAA's National Airport Pavement Test Facility (NAPTF). While a number of load repetitions $N$ increases, the rut depth of airport runways is also growing regardless of the number of wheels in the airplane chassis.

The procedure for designing an asphalt mix specifies a range in air void content from $3 \%$ to $5 \%$. However, actual variability in the air void content of the road surface varies more because of differences in temperature and compacting. With reference to Michigan transport department, the tolerance of air void content in the compacted asphalt mixture is $\pm 1 \%$ from the target air void content of $3 \%$ to $5 \%$. Therefore, practical and permissible variability in air void content is $2-6 \%$. In practice, the in-place air void content of the existing pavements varies across the lane (in the transverse direction) because of additional compaction in wheel paths due to traffic. This leads to differences in percent air voids across the asphalt mat. Such differences are independent of segregation (Chang et al. 2002). Therefore, ruts appear in the wheel rolling strips of compressed asphalt.

Rut parameters are affected by aggregate structure (Khedr, Breakah 2011; Lin, Cao 2009; Nukuhya et al. 2002), angularity (Souza et al. 2012; Topal, Sengoz 2005), moisture (Hajj et al. 2011b) and HMA density (Mogawer et al. 2011).

The Georgia department of Transportation typically uses relatively large maximum-size aggregates to ensure that base and binder course mixtures are resistant to rutting (Brown et al. 1989).

Latvian scientists (Haritonovs et al. 2010) described the asphalt coating mixture and their resistance to load after assessing the actual characteristics of road surface operation.

de Freitas et al. (2005) present the findings of a study seeking to quantify the effect of those factors on top-down cracking (TDC). The study consists of a laboratory component involving an accelerated wheeltracking device and a modelling component involving a 3D non-linear viscoelastic finite element model.

Apeagyei (2011) study was conducted to investigate the rutting resistance of asphalt concrete (AC) mixtures as a function of dynamic modulus $\left(\left|\mathrm{E}^{*}\right|\right)$ and gradation. Rutting was simulated using a flow number
(FN) test. FN tests conducted at $54.4{ }^{\circ} \mathrm{C}$ were used for rutting simulation in $16 \mathrm{AC}$ mixtures in the laboratory. The possibility of predicting rutting resistance to asphalt mixtures from dynamic modulus and gradation has many potential practical implications and requires further investigation. Dynamic modulus $\left(\left|\mathrm{E}^{*}\right|\right)$ is one of the fundamental properties defining the response of hot-mix asphalt (HMA) mixtures to flexible pavement systems (Ceylan et al. 2009; Salama et al. 2007).

Said et al. (2011) evaluate an approach to predicting rut formation in AC layers. The approach is based on a viscoelastic model for predicting permanent vertical strain in AC layers subjected to a moving load. The approach is capable of calculating rutting profiles including the upheaval important for estimating rut depth.

Ali et al. (2009) concern the analysis of rutting urban pavements using finite-element modelling, which takes into account the non-linear behaviour of pavement materials and complex traffic conditions. The model is used for the examination of rutting in the urban pavement and for studying rehabilitation methods. The performed analysis shows that urban traffic conditions are detrimental for urban pavements and the use of high resistance $\mathrm{AC}$ constitutes an efficient alternative for urban pavement rehabilitation.

Coleri et al. (2008) demonstrate the applicability of the integrated Weibull approach to simulating the in situ rutting performance of $\mathrm{AC}$ mixes by applying appropriate correction factors to laboratory models. Correction factors were used for calibrating laboratory equations according to deflection data from four test sections of a heavy vehicle simulator to estimate in situ rutting performance. The results indicate that phase separation occurs at higher repetition values with increasing shear stress.

The dependence of rutting evolution on stress state was verified, and a model relating rut depth to load repetition was derived (Malysz et al. 2012). A laboratory study was carried out to verify if pavement rutting could be estimated by permanent strain laboratory testing.

Collop et al. (2006) investigate the use of discrete element modelling to simulate the behaviour of a highly idealised bituminous mixture under uniaxial and triaxial compressive creep tests. The idealised mixture compresses single-sized spherical (sand-sized) particles mixed with bitumen and has been chosen so that packing characteristics are known (dense random packing) and the behaviour of the mixture will be dominated by the bitumen and complex aggregate interlock effects will be minimised. An elastic contact has been assumed for compressive normal contact stiffness and a viscoelastic contact for shear and tensile normal contact stiffness to respect contact behaviour in the idealised mixture. The models of 
different binders not assembled by multi-sphere and elliptical particle contact (inter-particle contact) were created by Markauskas et al. (2010).

Dawson (2008) studied the applicability and limits of applicability of the fourth-law to typical low-volume road pavements with no or only thin seals that obtain their structural performance primarily from the aggregate base (or equivalent) layer and for which pavement deterioration is overwhelmingly due to rutting. Rutting does not develop linearly with the number of contact axle loads; thus, it cannot be expected to increase linearly with ESALs. In this way, the frequent implicit use of power law approaches is deprecated (Dawson 2008).

The approach (Lottoman, Frith 1989) to predicting moisture sensitivity of AC pavements is based on the acceleration of fatigue cracking and field distress of wheel path rutting. Prediction methods incorporate the mechanical properties of the specimen, derived physical property rations with field time and environmental effects. In this case, moisture effects on wheel path rutting as changes in the permanent deformation of $\mathrm{AC}$ due to plastic flow are defined.

Styrene butadiene styrene and starch have been used by many to modify asphalt cement and to improve the properties of AC. The basic properties of modified asphalt binders and stone mastic asphalt concrete (SMAC) containing the above-introduced asphalt binders were studied and compared with those of asphalt cement (Al-Hadidy, Yi-qiu 2010). SMAC was tested carrying out experiments on Marshall stability, Marshall Quotient, tensile strength, tensile strength ratio, rutting resistance, flexural strength and resilient modulus.

Gokhale et al. (2005) presents a description of the testing program, data collection effort and subsequent analyses and findings focusing primarily on the initiation mechanisms of rutting in asphalt mixtures as generated and observed under accelerated pavement testing. The analysis of data on rutting indicates that unmodified $\mathrm{AC}$ mixtures are rutted significantly more than modified mixtures under similar loading and temperature conditions.

The content, structure and characteristics of a HMA mixture used for constructing a pavement layer designed under deterministic (Sivilevičius et al. 2011) or stochastic (Sivilevičius, Vislavičius 2008) methods depend on HMA manufacture in asphalt-mixing plant tolerance (Bražiūnas, Sivilevičius 2010; Sivilevičius 2011b).

After a scale of pavement damage to road asphalt has reached an intolerable limit, a surface or binder course is recycled in a hot manner using an inplace or in-plant method adding new minerals and old asphalt properties rejuvenating binders (Čygas et al. 2011; Mučinis et al. 2009). For the purposes of the current analysis (Zaghloul, Holland 2008), a pavement section is assumed to be reconstructed when its structural adequacy index reaches a value of 0.5 .

Apeagyei et al. (2011) evaluated the rutting resistance of plant-produced $\mathrm{AC}$ mixtures in the laboratory. Nineteen plant-produced AC mixtures were used; the mixtures contained reclaimed asphalt pavement (RAP) the amounts of which ranged from $0 \%$ to $25 \%$. The mixtures that contained no RAP showed dynamic modulus $\left(\left|\mathrm{E}^{*}\right|\right)$ values comparable to those that contained $25 \%$ of RAP in most cases. For most of tested 19 mixtures, those having a lower FN contained no RAP, $25 \%$ of RAP or had PG $64-22$ as the design binder grade. Statistical analysis showed that the amount of RAP was the most significant factor in affecting rutting resistance in the studied mixtures

Capuruco et al. (2005) present a new statistic term - full-car roughness index used for calculating pavement roughness from longitudinal pavement profiles. The index has been developed to better simulate the interaction between the vehicle and the road.

Solowczuk (2011) presents the findings of the impact of rut depth on $85 \%$ of speed quantile, $v_{85}$ along with information about average speeds for vehicles carrying passengers and goods as well as speeds reached at various available stopping sight distances.

Fwa et al. (2012) introduce an analytical procedure for assessing the severity of rutting based on vehicle skidding and hydroplaning analysis. For the given rut depth filled with water, the computer model computes a hydroplaning speed of a typical passenger car and the required braking distance of the car travelling at the known speed. Fwa et al. (2012) have presented an approach to determining the threshold of a critical rut depth of pavement maintenance based on the consideration of hydroplaning risk and safety requirements for braking distance.

Vehicle manufacturers place a major focus on improving the design of vehicle components to better respond to changes in road surface profiles (Zaabar, Chatti 2011). Nevertheless, changes in the surface profile still directly affect user costs, including repair and maintenance costs and damage to goods.

The permissible depth of the rut and the assessment of the pavement based on this indicator (rut depth) are very important. These requirements and indicators fundamentally differ in separate countries, where in some of which only the mean $h_{\mathrm{m}}$ of rut depth is assessed and some estimate a standard deviation of depth $s_{\mathrm{h}}$.

The average depth of asphalt cover tracks started to be limited in the Netherlands a few decades ago (Elsenaar, van de Fliert 1977) - they were not to be deeper than $20 \mathrm{~mm}$. Permissible rut depth in Norway, depending on the category of the road, ranges from 20 
to $35 \mathrm{~mm}$. The permissible rut depth of highways in Germany is $7 \mathrm{~mm}$. Moreover, it cannot exceed $2 \mathrm{~mm}$ during their first 2 years of operation. Fifteen millimetre rut depth is considered critical in the UK and $20 \mathrm{~mm}$ depth is deemed unacceptable in all cases (Vasiliev 1999).

In Switzerland, the condition of the surface is measured not only by rut depth $h$ but also by the depth of water level inside it $h_{\mathrm{v}}$. In France, water level in the rut is also standardised and, depending on traffic, ranges from 6 to $12 \mathrm{~mm}$. In Poland, the depth of the rut is assessed according to its effect on traffic safety. All ruts are divided into four separate categories: 0, I, II and III for different road classes. Unfortunately, there is a lack of literature (publications) about requirements for permissible rut depth and justification principles and methods of road condition assessment indicators according to this parameter (Vasiliev 1999). Lithuania has established $20 \mathrm{~mm}$ permissible rut depth without specifying whether it is the mean, or one single value. There are also no requirements for the standard deviation $s_{\mathrm{h}}$ of rut depth. When verifying the condition of operating roads covered with the asphalt pavement, the total percentage of road sections having deeper than $20 \mathrm{~mm}$ ruts is counted. The article presents one of the first attempts to measure rut depth on Lithuanian roads and display the obtained statistics (Getautis, Sivilevičius 2009).

Using a variety of multi-criteria evaluation methods, the risk of construction projects is determined thus selecting the best alternatives and maximum benefit (Zavadskas, Turskis 2011; Zavadskas et al. 2010). The given methods can be adjusted to analysing the factors affecting the ruts that appear in the asphalt pavement on the road and to finding the most appropriate solution.

\section{Factors determining and assessing rutting}

The roughness of the road surface, assessed by IRI, depends on the size of fatigue cracks and the average depth of ruts (Caliendo 2012; Loizos, Plati 2008). When input data are implemented and a distress model is calibrated for local conditions, the Mechanistic-Empirical Pavement Design Guide (MEPDG) automatically predicts the corresponding IRI over time (Rajbongshi, Das 2008). The equation used is as follows:

$$
\begin{aligned}
\mathrm{IRI}= & \mathrm{IRI}_{0}+0.015(\mathrm{SF})+0.400\left(\mathrm{FC}_{\text {total }}\right)+ \\
& 0.008(\mathrm{TC})+40.0(\mathrm{RD}),
\end{aligned}
$$

where: $\mathrm{IRI}_{0}$ - initial IRI after construction; SF - site factor; $\mathrm{FC}_{\text {total }}$ - the area of fatigue-cracking (combined alligator, longitudinal and reflection cracking in the wheel path); TC - the length of transverse cracking; RD - average rut depth.
Rut depth caused by flow rutting is modelled as a function of elastic strain, temperature and the number of loadings, as shown in the MEPDG equation (NCHRP 2004; Oscarsson 2011):

$$
\begin{gathered}
\frac{\varepsilon_{p}}{\varepsilon_{r}}=k_{1} a_{1} \beta_{r 1} T^{a_{2} \beta_{r 2}} N^{a_{3} \beta_{r 3}} ; \\
\mathrm{RD}=\sum_{i=1}^{n}\left(\varepsilon_{p}\right)_{i} h_{i},
\end{gathered}
$$

where: $\varepsilon_{p}$ is accumulated plastic strain at $N$ load repetitions; $\varepsilon_{r}$ is the resilient strain of the asphalt material; $k_{1}$ is the variable confining pressure factor as a function of depth; $a_{i}$ is laboratory-determined nonlinear regression coefficients; $\beta_{r 1}$ is laboratory to field calibration factors; $N$ is the number of loaded repetitions, $T$ is temperature $\left({ }^{\circ} \mathrm{F}\right)$; $\mathrm{RD}$ is rut depth (in.); $n$ is the number of AC sub-layers; and $h_{\mathrm{i}}$ is the thickness of a sub-layer (in.).

The latest development of predicting rutting within the HMA layer calls for determining plastic vertical compressive strain within the HMA layer. The total rutting within the HMA layer is then calculated by multiplying the permanent strain times the thickness of the HMA layer (Hajj et al. 2011a; Shukla, Das 2008):

$$
\mathrm{RD}_{\mathrm{HMA}}=\varepsilon_{p} \cdot h_{\mathrm{AC}},
$$

where: $\mathrm{RD}_{\mathrm{HMA}}$ is rutting generated in the HMA layer; $\varepsilon_{p}$ is permanent strain within the HMA layer; and $h_{\mathrm{AC}}$ is the thickness of the HMA layer.

With reference to available literature (Kannemeyer 2003), the majority of the developed models of the ruts observed in asphalt base pavements evaluate materials not acceptable producing such types of pavements within the existing HDM-III models. The following rut development model is employed for predicting the expected rut depth:

$$
\mathrm{RD}=a+b \cdot T,
$$

where: RD - predicted rut depth, mm; $a, b-$ parameters the value of which depends on the type of the road base; $T$ - cumulative traffic carried in million standard axles and equal to YE4 used in HDM-III, assuming a load equivalency factor of 4 .

Malysz et al. (2012) discuss the permanent deformation behaviour of unbound aggregates used in accelerated pavement test (APT) sections. The dependence of rutting evolution on stress state was verified, and a model relating rut depth to load repetition was derived. Rut depth in APT test sections was noticeably greater than that expected from permanent deformation in the specimens of the triaxial apparatus. 
The subgrade showed almost no contribution on rutting, and the surface treatment is too thin to cause any effects:

$$
\mathrm{RD}=a+b \cdot \sqrt{N},
$$

where: RD - rutting depth; $N$ - the number of cycles; $a$ and $b$ - statistical regression parameters.

The theoretical pavement life of rutting resistance (known as the theoretical pavement rutting life index) was calculated using the Eqn. (7) below (Goh et al. 2011):

The theoretical pavement rutting life index (TPRLI)

$$
=\frac{\text { Rutting }_{\text {Allow }}}{\text { Rutting }_{\text {Actual }}} \text {, }
$$

where: TPRLL is the theoretical pavement rutting life index, an index value that indicates the theoretical pavement rutting life in the field (year); Rutting Allow $_{-}$ allowable maximum rutting ( 0.25 in); Rutting Actual actual rutting in the field per year (in/year).

According to the HDM-4 programme drawn up by an order of the World Bank, one of the main pavement quality indicators is average rut depth $h_{\mathrm{m}}$ and the standard deviation $s_{\mathrm{h}}$ of rut depth (Kannemeyer 2003) determining the condition of the surface (Table 1).

Taniguchi and Yoshida (2003) mention the calibration of the HDM-4 rutting model on Japanese national highways and compare the HDM-4 rutting model with the rutting prediction model included in the Pavement Management System developed by the Ministry of Land, Infrastructure Transportation of Japan (MLIT-PMS). The maintenance control index (MCI) of MLIT-PMS is given by the following expression:

$$
\mathrm{MCI}=10-1.48 C^{0.3}-0.29 D^{0.7}-0.47 \sigma^{0.2},
$$

where: $C$ - the amount of cracking, $\% ; D$ - rut depth, $\mathrm{mm} ; \sigma-$ longitudinal roughness, $\mathrm{mm}$.

Table 1. Permissible parameters of rut depth (mm)

\begin{tabular}{lccccc}
\hline & \multicolumn{5}{c}{ Condition of the pavement surface } \\
\cline { 2 - 6 } $\begin{array}{l}\text { Statistical } \\
\text { indicator }\end{array}$ & New & Good & Satisfactory & Unsatisfactory & Bad \\
\hline $\begin{array}{l}\text { Mean rut } \\
\text { depth }\end{array}$ & 0 & 2 & 5 & 15 & 25 \\
$\begin{array}{l}\left(h_{\mathrm{m}}\right) \\
\begin{array}{l}\text { Standard } \\
\text { deviation }\end{array}\end{array}$ & 0 & 1 & 2 & 5 & 8 \\
$\begin{array}{l}\text { of rut } \\
\text { depth }\left(s_{\mathrm{h}}\right)\end{array}$ & & & & & \\
\hline
\end{tabular}

Table 2. The dependence of maintenance levels on the MCI (Taniguchi, Yoschida 2003)

\begin{tabular}{ll}
\hline MCI & \multicolumn{1}{c}{ Management level } \\
\hline More than 5 & $\begin{array}{l}\text { Not needing repair (desirable management } \\
\text { level) } \\
\text { Needing repair }\end{array}$ \\
$3-5$ & Needing immediate repair \\
Less than 3 & Neding \\
\hline
\end{tabular}

The management criteria of the MCI in actual road management are provided in Table 2. In order to evaluate the road and automobile stability in motion on the uneven surface with ruts, the following criterion is suggested (Vansauskas, Bogdevičius 2009):

$$
\mathrm{MBV}=\frac{1}{g I_{z_{\mathrm{c}}}} \sqrt{\frac{1}{T} \int_{0}^{T} M_{z_{\mathrm{c}}}^{2}(t) \mathrm{d} t,}
$$

where: $M_{z_{\mathrm{c}}}$ is the summary moment of cohesion forces around body axis $z$; Tis general movement time; $I_{z_{\mathrm{c}}}$ is the overall automobile mass moment of inertia around axis $z ; g$ is gravity acceleration.

The performed analysis shows that ruts on the asphalt pavement are formed by heavy vehicles (Perera, Kohn 2004), and, because of their large and frequently changing depth, mainly suffer fast travelling private cars. Therefore, not only the average rut depth is important but also its variation causing the driver surprise and confusion effect. The statistical parameters of rut depth have been improperly investigated and still remain interesting to science and the field of study.

\section{Methodology for rut measurement and data processing}

The problem of rutting has been relevant and yet unresolved in Lithuania as well as in other countries. Ruts become deeper as heavy vehicles drive on highways and other country roads. With no timely corrections to the pavement in a few years' time rutting would exceed the limit depth of $20 \mathrm{~mm}$ and reach a critical depth of $40 \mathrm{~mm}$, which would inevitably increase the number of traffic accidents.

The staff of the Transport and Road Research Institute (TKTI) annually monitors the rut depth of the roads of national significance (18 highways and 132 regional) every $20 \mathrm{~m}$. The obtained data have been used for assessing the condition of country roads. Mobile Road Research Laboratory RST 28 is used for performing measurements.

Rut depth on roads is measured in both travel directions of each lane, including the left and right wheel. Rut distribution in transverse road direction schemes (Fig. 1) for highways Vilnius-Kaunas with a dividing strip and Vilnius-Minsk are presented as an example. While driving the mobile laboratory at a 


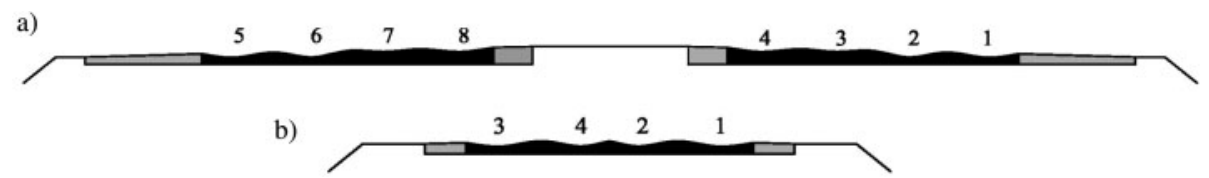

Fig. 1. The distribution of eight ruts (a) and four ruts (b) of a transverse track direction

speed of $v_{\text {RST } 28}=80 \mathrm{~km} / \mathrm{h}$, only the ruts deeper than surface texture depth have been measured.

According to geometrical data on TKTI rut measurement, calculations were made and statistical indicators showing the rut depth of highways were obtained (Table 3). A rut number in Table 3 fits the numbers presented in the schemes of Figure 1.

The mean of rut depth $h_{\mathrm{m}}$ (position indicator) and standard deviation $s_{\mathrm{h}}$ (dispersion indicator) of each longitudinal direction of the road were measured.

Every $20 \mathrm{~m}$ of measurement, unit data $h_{i}$ was used for calculating mean $h_{\mathrm{m}}$ of every separate rut of the road:

$$
h_{\mathrm{m}}=\frac{\sum_{i=1}^{n} h_{i}}{n},
$$

where: $h_{i}$ - the rut depth of the $i$-th measurement, mm; $n$ - the number of measurements $(i=1,2, \ldots, n)$.

Each standard deviation of rut $s_{h}$ was measured using similar data:

$$
s_{\mathrm{h}}=\sqrt{\frac{\sum_{i=1}^{n}\left(h_{i}-h_{\mathrm{m}}\right)^{2}}{n-1}},
$$

where: $h_{i}$ - the rut depth of the $i$-th measurement, mm; $n$ - the number of measurements; $h_{\mathrm{m}}-$ mean.

Statistic indicators of each rut ( 4 or 8 ) from all 18 highways are presented in Table 3 . They show that the deepest ruts of the road having a dividing strip equal $h_{\mathrm{m}}=8.69 \mathrm{~mm}$ and standard deviation makes $s_{\mathrm{h}}=5.81 \mathrm{~mm}$ (rut 1 on the A12 road) and the situation on the roads without a dividing strip $-h_{\mathrm{m}}=12.10 \mathrm{~mm}$ and $s_{\mathrm{h}}=5.38 \mathrm{~mm}$ (rut 2 on the A 8 road). An average depth of the smallest ruts of the least rutted roads having a dividing strip equal $h_{\mathrm{m}}=1.81 \mathrm{~mm}$ and standard deviation makes $s_{\mathrm{h}}=1.18 \mathrm{~mm}$ (rut 7 on the road A13) while the roads without a dividing strip $h_{\mathrm{m}}=2.98 \mathrm{~mm}$ and $s_{\mathrm{h}}=1.93 \mathrm{~mm}$.

A part of measurement data that shows the texture depth of the pavement surface is rejected and does not affect the pavement layer due to rutting. Therefore, the first interval (class) of histograms (Fig. 2) does not start from $h_{i \min }=0$ (zero) but from $h_{i \text { min }}$ having the values $0.3,0.4,0.5$ or $0.6 \mathrm{~mm}$.

After calculating $h_{\mathrm{m}}, s_{\mathrm{h}}$, the percentage coefficient of variation $V_{\mathrm{h}}$, the characteristics of the form of frequency distributions considering data grouped in the intervals of histograms were calculated: skewness $s k$ and kurtosis $-k u$.

Since all empirical values of histogram (Fig. 2) skewness $s k$ are higher than zero ( $s k$ varies from 1.08 to 6.94), the asymmetry of histograms is positive (right) and differs from the normal section. An empirical value of kurtosis $k u$ is also higher than zero ( $k u$ varies from 1.32 to 97.1$)$, thus, the peaks of the histograms are sharper than that of normal distribution (positive kurtosis).

Empirical skewness and kurtosis of the histograms were compared with critical values depending on the size of sample $n$ only. For that reason, standard deviations of skewness and kurtosis were calculated:

$$
s_{s k}=\sqrt{\frac{6 n(n-1)}{(n-2)(n+1)(n+3)}}
$$

and

$$
s_{k u}=\sqrt{\frac{24 n(n-1)^{2}}{(n-3)(n-2)(n+3)(n+5)}} .
$$

When $|s k| \leq 3 s_{s k}$ and $|k u| \leq 5 s_{k u}$, it can be considered that the normality hypothesis of empirical data is accepted. Otherwise, the raised hypothesis is rejected or accepted as doubtful.

Considering sample sizes $n=11.669$ and $n=$ 14.569 of the Vilnius-Kaunas-Klaipeda highway shown in Table 3 and Fig. 2, the values of standard deviations were calculated according to Eqns (12) and (13): $s_{s k}=0.0002099$ and $s_{s k}=0.0001681, s_{k u}=0.0453$ and $s_{k u}=0.0406$. The values of skewness $s_{s k}$ multiplied by 3 , which are 0.00063 and 0.0050 , respectively, are much lower than $s k$ values calculated from measurement data given in the histograms (Fig. 2). The values of kurtosis $s_{k u}$ multiplied by 5, which are 0.227 and 0.203 respectively, are much lower than $k u$ values calculated from measurement data given in the histograms (Fig. 2). These data reasonably lead to the conclusion that the depth of the ruts distributes not according to the normal law.

With an increase in rut depth $h_{\mathrm{m}}$, average skewness and kurtosis decrease (Fig. 3). This correlation implies that the deeper is the road rut, the closer to the individual sections of rut depth is the dissemination of normal distribution.

According to the calculated values of skewness and kurtosis, Uddin et al. (2012) assessed the nonnormality of data on highway construction. 
Table 3. Statistical indicators of the rut depth of the highway asphalt layer

\begin{tabular}{|c|c|c|c|c|c|c|c|c|c|}
\hline \multirow[b]{2}{*}{ Name and number of the road } & \multicolumn{9}{|c|}{$\begin{array}{c}\text { Rutting measured every } 20 \mathrm{~m} \text {, number of readings } n \text {, mean } h_{\mathrm{m}} \text {, standard } \\
\text { deviation } s_{\mathrm{h}}\end{array}$} \\
\hline & Rut No. & 1 & 2 & 3 & 4 & 5 & 6 & 7 & 8 \\
\hline \multirow[t]{3}{*}{ A1 (Vilnius-Kaunas-Klaipėda) } & $n$ & \multicolumn{2}{|c|}{14567} & \multicolumn{2}{|c|}{14596} & \multicolumn{2}{|c|}{11669} & \multicolumn{2}{|c|}{11969} \\
\hline & $h_{\mathrm{m}}$ & 6.07 & 6.93 & 2.52 & 3.12 & 7.72 & 7.53 & 2.64 & 3.29 \\
\hline & $s_{\mathrm{h}}$ & 4.88 & 4.77 & 1.71 & 1.97 & 5.47 & 4.95 & 1.54 & 2.07 \\
\hline \multirow[t]{3}{*}{ A2 (Vilnius-Panevėžys) } & $n$ & \multicolumn{2}{|c|}{6245} & \multicolumn{2}{|c|}{6041} & \multicolumn{2}{|c|}{6245} & \multicolumn{2}{|c|}{6246} \\
\hline & $h_{\mathrm{m}}$ & 6.24 & 7.08 & 1.94 & 2.21 & 6.37 & 6.89 & 2.04 & 2.70 \\
\hline & $s_{\mathrm{h}}$ & 5.09 & 5.33 & 1.17 & 1.42 & 4.27 & 5.06 & 1.92 & 2.15 \\
\hline \multirow[t]{3}{*}{ A3 (Vilnius-Minskas) } & $n$ & \multicolumn{2}{|c|}{1318} & \multicolumn{2}{|c|}{1323} & \multicolumn{2}{|c|}{-} & & \\
\hline & $h_{\mathrm{m}}$ & 4.40 & 3.97 & 3.47 & 3.59 & - & - & - & - \\
\hline & $s_{\mathrm{h}}$ & 3.50 & 3.02 & 2.56 & 2.43 & - & - & - & - \\
\hline A4 (Vilnius-Varèna-Gardinas) & $n$ & & & & & & & & \\
\hline & $h_{\mathrm{m}}$ & 4.75 & 4.63 & 4.79 & 4.45 & - & - & - & - \\
\hline & $s_{\mathrm{h}}$ & 3.47 & 3.68 & 3.47 & 3.46 & - & - & - & - \\
\hline A5 (Kaunas-Marijampole-Suvalkai) & $n$ & & & & & & & & \\
\hline & $h_{\mathrm{m}}$ & 6.83 & 6.82 & 3.17 & 5.13 & 4.01 & 4.79 & 2.75 & 4.30 \\
\hline & $s_{\mathrm{h}}$ & 8.56 & 7.39 & 2.47 & 3.61 & 4.33 & 3.85 & 2.28 & 3.03 \\
\hline A6 (Kaunas-Zarasai-Daugpilis) & $n$ & & & & & & & & \\
\hline & $h_{\mathrm{m}}$ & 8.58 & 8.02 & 4.94 & 6.77 & 7.94 & 7.17 & 2.63 & 2.91 \\
\hline & $s_{\mathrm{h}}$ & 6.27 & 5.44 & 2.81 & 3.94 & 6.45 & 5.49 & 2.14 & 2.31 \\
\hline A7 (Marijampolé-Kybartai-Kaliningradas) & $n$ & & & & & & & & \\
\hline & $h_{\mathrm{m}}$ & 3.24 & 3.41 & 2.98 & 3.38 & - & - & - & - \\
\hline & $s_{\mathrm{h}}$ & 2.10 & 1.95 & 1.93 & 1.80 & - & - & - & - \\
\hline A8 (Panevėžys-Aristava-Sitkūnai) & $n$ & & & & & & & & \\
\hline & $h_{\mathrm{m}}$ & 9.07 & 12.1 & 8.34 & 12.27 & - & - & - & - \\
\hline & $s_{\mathrm{h}}$ & 6.36 & 5.38 & 6.51 & 5.73 & - & - & - & - \\
\hline A9 (Panevėžys-Šiauliai) & $n$ & & & & & & & & \\
\hline & $h_{\mathrm{m}}$ & 6.98 & 7.86 & 6.58 & 8.09 & - & - & - & - \\
\hline & $s_{\mathrm{h}}$ & 5.12 & 4.50 & 4.62 & 4.67 & - & - & - & - \\
\hline A10 (Panevėžys-Pasvalys-Bauska) & $n$ & & & & & & & & \\
\hline & $h_{\mathrm{m}}$ & 9.59 & 9.10 & 9.34 & 9.43 & - & - & - & - \\
\hline & $s_{\mathrm{h}}$ & 8.56 & 8.40 & 8.22 & 8.77 & - & - & - & - \\
\hline A11 (Šiauliai-Palanga) & $n$ & & & & & & & & \\
\hline & $h_{\mathrm{m}}$ & 6.13 & 5.04 & 1.66 & 3.02 & 5.57 & 5.03 & 3.36 & 3.20 \\
\hline & $s_{\mathrm{h}}$ & 4.98 & 3.53 & 1.02 & 1.31 & 4.37 & 3.45 & 2.56 & 2.66 \\
\hline A12 (Ryga-Šiauliai-Tauragė-Kaliningradas) & $n$ & & & & & & & & \\
\hline & $h_{\mathrm{m}}$ & 8.69 & 8.53 & 1.14 & 2.03 & 7.14 & 7.86 & 2.21 & 3.04 \\
\hline & $s_{\mathrm{h}}$ & 5.81 & 4.87 & 1.29 & 2.24 & 5.04 & 4.36 & 1.39 & 1.67 \\
\hline A13 (Klaipèda-Liepoja) & $n$ & & & & & & & & \\
\hline & $h_{\mathrm{m}}$ & 6.12 & 5.25 & 2.14 & 5.01 & 4.04 & 4.74 & 1.81 & 3.16 \\
\hline & $s_{\mathrm{h}}$ & 5.34 & 3.47 & 1.86 & 5.40 & 2.30 & 3.22 & 1.18 & 1.43 \\
\hline A14 (Vilnius-Utena) & $n$ & & & & & & & & \\
\hline & $h_{\mathrm{m}}$ & 5.49 & 5.22 & 4.78 & 4.13 & - & - & - & - \\
\hline & $s_{\mathrm{h}}$ & 2.57 & 3.35 & 2.72 & 3.20 & - & - & - & - \\
\hline A15 (Vilnius-Lyda) & $n$ & & & & & & & & \\
\hline & $h_{\mathrm{m}}$ & 4.80 & 5.12 & 4.40 & 4.71 & - & - & - & - \\
\hline & $s_{\mathrm{h}}$ & 3.82 & 3.79 & 3.38 & 3.45 & - & - & - & - \\
\hline A16 (Vilnius-Prienai-Marijampolè) & $n$ & & & & & & & & \\
\hline & $h_{\mathrm{m}}$ & 4.78 & 3.80 & 3.85 & 3.32 & - & - & - & - \\
\hline & $s_{\mathrm{h}}$ & 4.34 & 3.06 & 3.44 & 2.90 & - & - & - & - \\
\hline A17 (bypass of Panevėžys) & $n$ & & & & & & & & \\
\hline & $h_{\mathrm{m}}$ & 6.20 & 8.47 & 6.03 & 8.50 & - & - & - & - \\
\hline & $s_{\mathrm{h}}$ & 5.24 & 4.44 & 5.11 & 4.37 & - & - & - & - \\
\hline A18 (bypass of Šiauliai) & $n$ & & & & & & & & \\
\hline & $h_{\mathrm{m}}$ & 4.60 & 3.99 & 4.23 & 3.43 & - & - & - & - \\
\hline & $s_{\mathrm{h}}$ & 2.94 & 2.90 & 2.77 & 2.55 & - & - & - & - \\
\hline
\end{tabular}



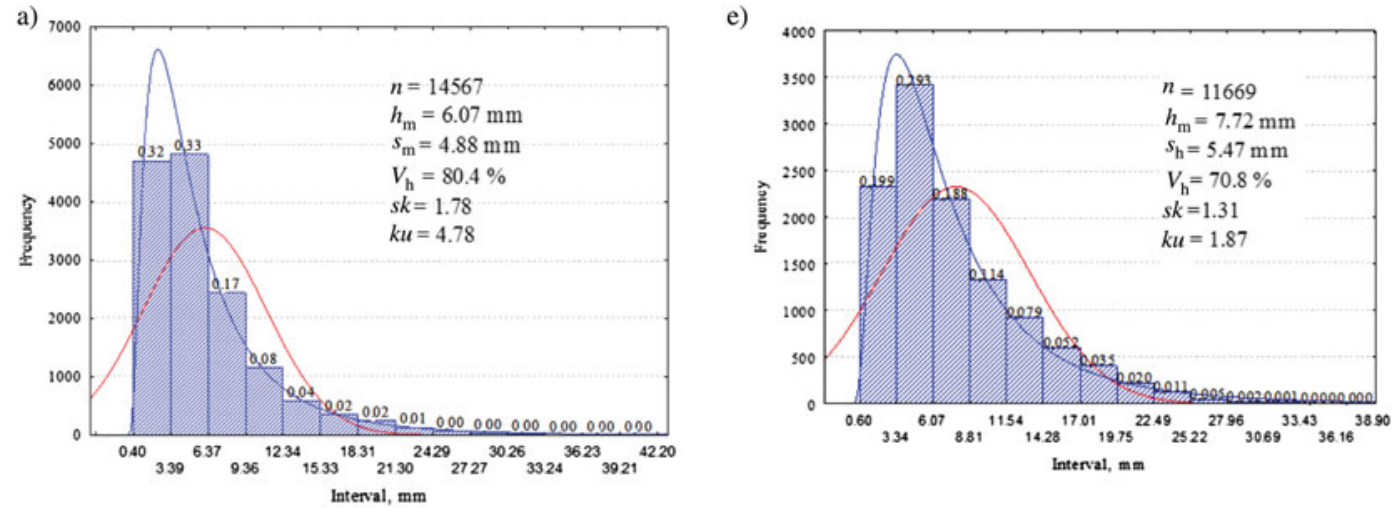

b)
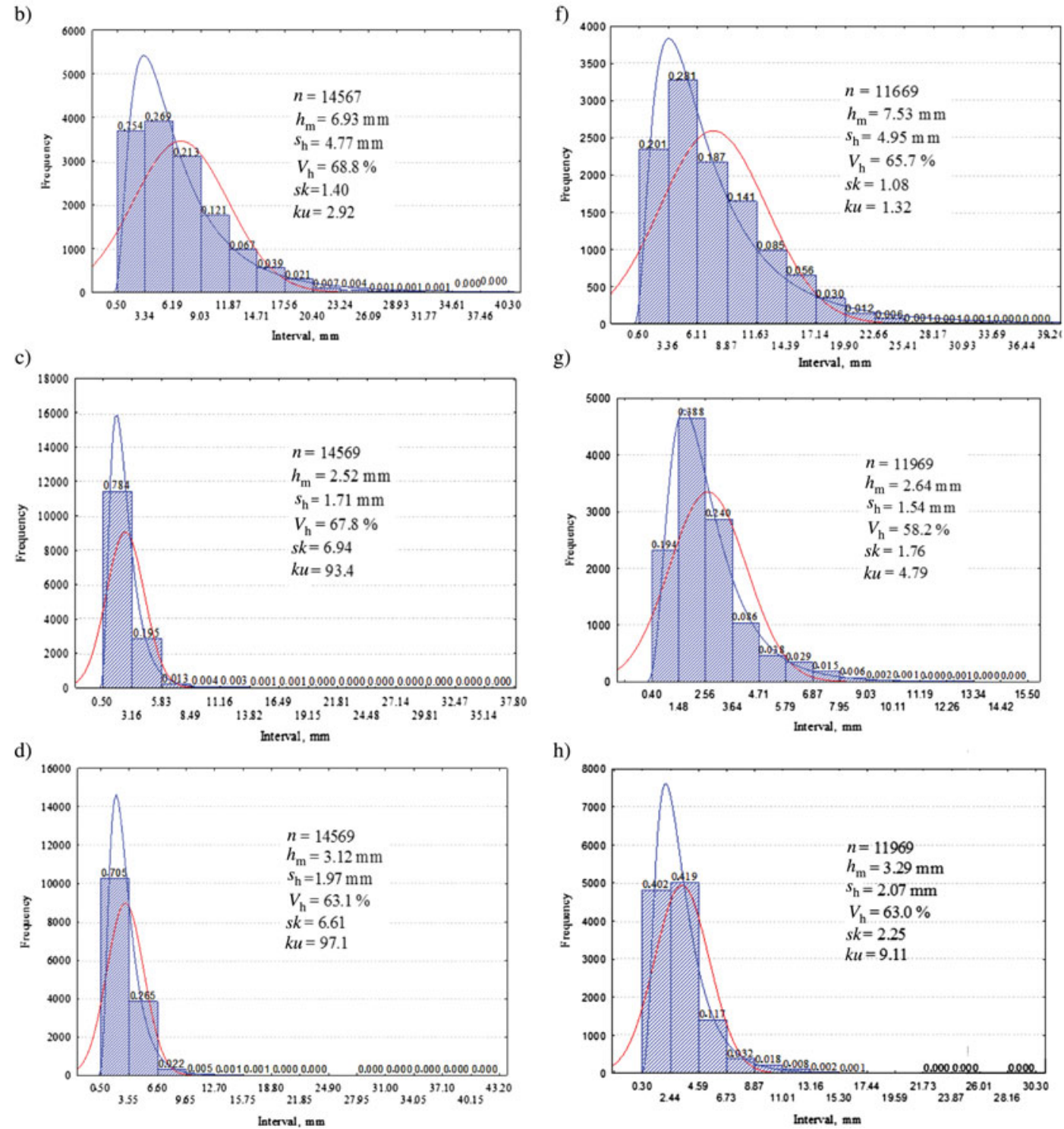

Fig. 2. The histograms of rut depth on the A1 highway, theoretical curves of normal and lognormal distribution and statistical indicators a-d of Vilnius-Kaunas-Klaipeda rutting $(1,2,3,4)$ and $\mathrm{e}-\mathrm{h}$ of Klaipeda-Kaunas-Vilnius rutting $(5,6$, $7,8)$

The value of the variation coefficient of a quite large sample taken from normal general wholeness should not be higher than $33 \%$. A high percentage of variation coefficient $V$ of rut depth (from $58.2 \%$ to
$80.4 \%$ ) shows that data (Fig. 2) are not distributed according to normal distribution.

The analysis of the histograms of the grouped study data discloses they are close to lognormal or 


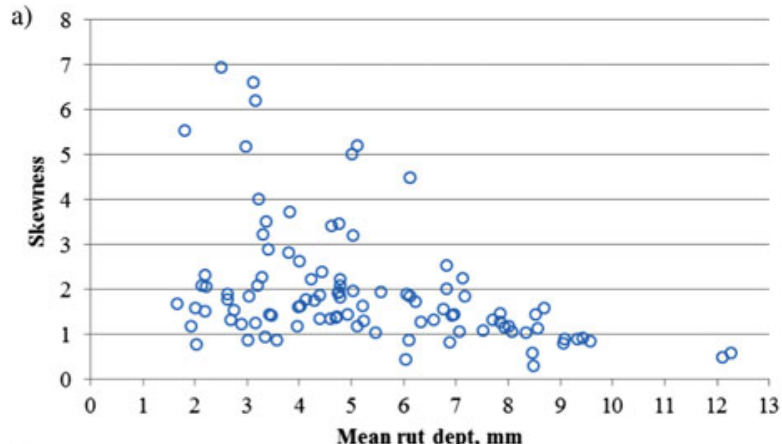

b)

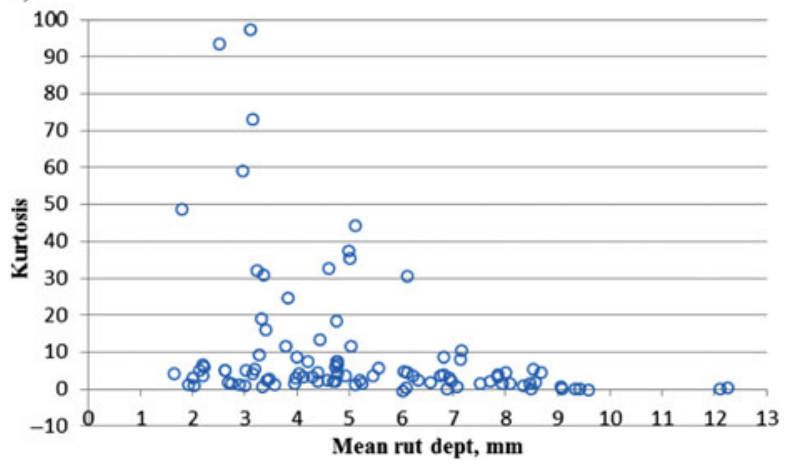

Fig. 3. The impact of average rut depth $h_{\mathrm{m}}$ on its individual sections of the proximity of depth distribution (compliance with normal distribution) in terms of: $a$ - skewness; $b-$ kurtosis

exponential distribution. Lognormal distribution (Billot et al. 2009) has the probability density function:

$$
f(x, \mu, \sigma)=\frac{1}{x \sigma \sqrt{2 \pi}} \exp \left[-\frac{(\ln x-\mu)^{2}}{2 \sigma^{2}}\right],
$$

where $\mu$ and $\sigma$ are the mean and standard deviation of the logarithm of variable $x$, respectively.

The curves of the probability density function of normal distribution and lognormal distribution (Fig. 2) drawn from histogram data differ fundamentally indicating that rut depth is closer to lognormal distribution.

All eight parameters of depth positioning $\left(h_{\mathrm{m}}\right)$ and dispersion $\left(s_{\mathrm{h}}\right)$ of the ruts on the roads with a separating strip indicate that the right lane has the deepest ruts as mainly heavy vehicles drive along them. Figure 4a indicates that each lane has a deeper rut on the right. The ruts of the reconstructed road (Road A13) are deeper because at the beginning it had no separating strip, and following many years, the second new two-lane carriageway was built (5-8 ruts). The rutting depth of the second lane is lower as mainly passenger cars drive there.

The average depth $h_{\mathrm{m}}$ of the investigated road rutting (the number of them $N=100$ ) is growing along with its standard deviation $s_{\mathrm{h}}$ (Figs 4 and 5). A positive linear correlation (Fig. 5) between the above-introduced statistical indicators has been found, and the received regression equations $s_{\mathrm{h}}=f\left(h_{\mathrm{m}}\right)$ and $s_{\mathrm{h}}^{2}=f\left(h_{\mathrm{m}}\right)$ show a sufficiently strong link between these indicators (determination coefficients $R^{2}$ are 0.74 and 0.61 , respectively).

Permissible rut depth after performing more statistical studies and the dynamic parameters of the cars travelling at a different speed after calculating the influence of rut depth can be determined. While defining permissible and critical rut depth, national economic opportunities and a strategy for reducing accidents must be evaluated.
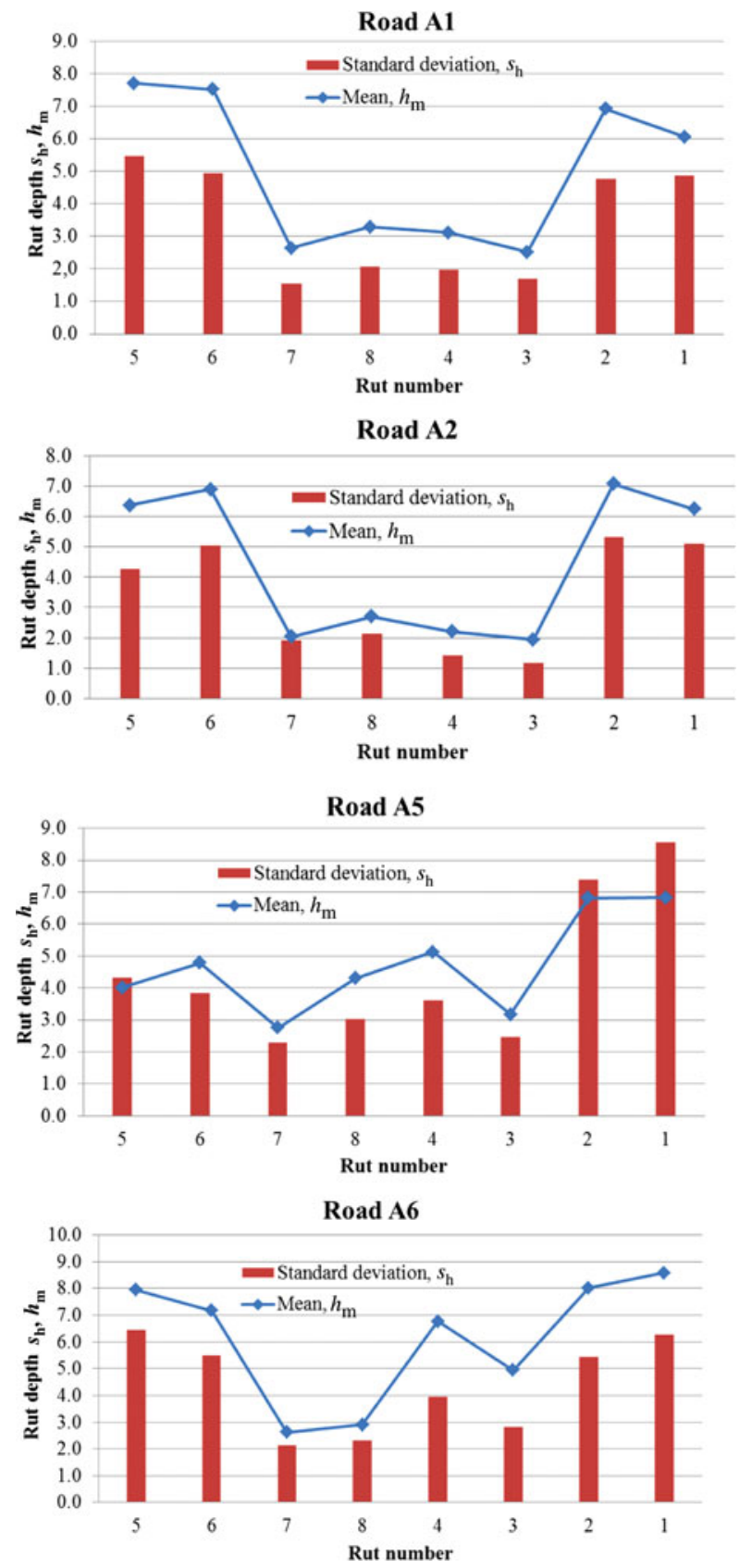

Fig. 4. (ends on page 618) 

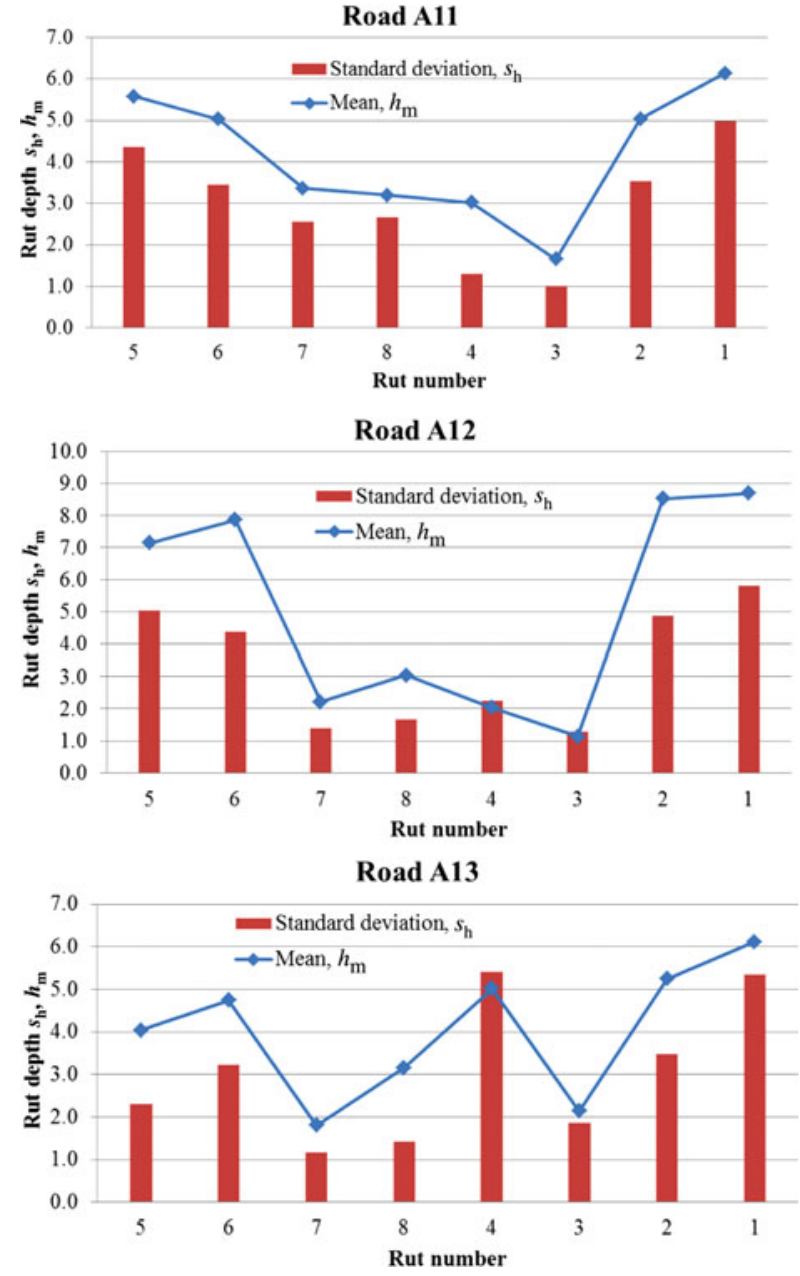

Fig. 4. (Continued) Statistical data on the distribution of rut depth on Lithuanian highways having a dividing strip in the transverse direction

\section{Conclusions}

1) After measuring the rut depth of each 18 Lithuanian highways every $20 \mathrm{~m}$ applying the mobile laboratory RST 28 , large samples ( $n=$ 454-14.567) were used for calculating arithmetical mean $h_{\mathrm{m}}$, standard deviation $s_{\mathrm{h}}$ and variation coefficient $V$ of rut depth. Skewness $(s k)$ and kurtosis $(k u)$ were calculated, histograms were drawn, normal and lognormal theoretical curves of the probability density of distribution were grouped into intervals considering the obtained information. Statistical data show that:

$-h_{\mathrm{m}}, s_{\mathrm{h}}$ and $V$ of the right and left rut of each lane differ: the roads having a dividing strip in the first lane, which is mainly driven by heavy vehicles, have deeper rutting, and deeper ruts can be noticed on the right side of the first lane;

- rut depth is not distributed according to normal distribution;

- without measuring and evaluating ruts, the depth of which is less than the depth of the
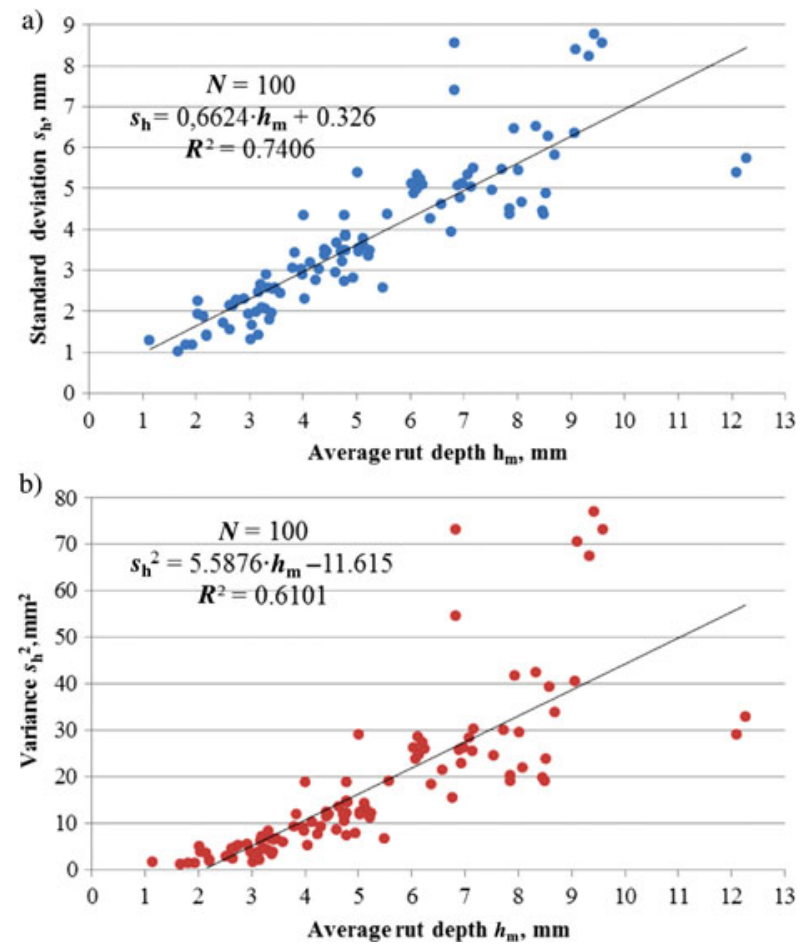

Fig. 5. The dependence of fraction indicators of rut depth on position indicators: $a$-standard deviation and arithmetical mean; $b$-variance and arithmetical mean

pavement surface texture, the depth of deeper (real) ruts distributes according to lognormal distribution;

- the bigger is the mean of rut depth, the closer its depth distribution gets to normal distribution;

- while the mean $h_{\mathrm{m}}$ of the rut depth of the road pavement is linearly increasing, the standard deviation $s_{\mathrm{h}}$ of its depth is also increasing (coefficient of determination $\left.R^{2}=0.74\right) ; h_{\mathrm{m}}$ and a linear positive correlation of variance $s_{\mathrm{h}}^{2}$ are weaker $\left(R^{2}=0.61\right)$.

2) While rut depth is increasing, its dispersion (variance) is also rising, which causes not only greater dynamics of the vehicle but also driving inconveniences, greater emotional stress and fatigue for the driver, which increases the number of accidents. The variation of rut depth rises the surprise appearance of a dangerous road section, the necessity of decreasing speed, the probability of driver's confusion (disorder), especially when the rut is filled with water. Rut depth is limited and must not exceed permissible and critical values that may differ in separate countries due to set employed different principles and methods. It is only possible to standardise maximum permissible rut depth after thorough additional tests based on the influence of geometrical rut parameters determining the dynamics of driving a car. 


\section{References}

Al-Hadidy, A. I.; Yi-qiu, T. 2010. Comparative performance of the SMAC made with the SBS- and ST-modified binders, Journal of Materials in Civil Engineering ASCE 22(6): 580-587.

http://dx.doi.org/10.1061/(ASCE)MT.1943-5533.0000057

Ali, B.; Sadek, M.; Shahrour, I. 2009. Finite-element model for urban pavement rutting: analysis of pavement rehabilitation methods, Journal of Transportation Engineering ASCE 135(4): 235-239.

http://dx.doi.org/10.1061/(ASCE)0733-947X(2009)135: $4(235)$

Al-Suleiman, T. I.; Obaidat, M. T.; Abdul-Jabbar, G. T.; Khedaywi, T. S. 2000. Field inspection and laboratory testing of highway pavement rutting, Canadian Journal of Civil Engineering 27(6): 1109-1119.

http://dx.doi.org/10.1139/cjce-27-6-1109

Apeagyei, A. K. 2011. Rutting as a function of dynamic modulus and gradation, Journal of Materials in Civil Engineering ASCE 23(9): 1302-1310.

http://dx.doi.org/10.1061/(ASCE)MT.1943-5533.0000309

Apeagyei, A. K.; Diefenderfer, B. K.; Diefenderfer, S. D. 2011. Rutting resistance of asphalt concrete mixtures that contain recycled asphalt pavement, Transportation Research Record 2208: 9-16. http://dx.doi.org/10.3141/2208-02.

ASTM E 867-02a. 2004. Terminology Relating to VehiclePavement Systems. Annual Book of ASTM Standards. Section four. Construction. Volume 04.03. Road and Paving Materials; Vehicle-Pavement Systems, 969-976.

Billot, R.; El Fanazi, N. E.; De Vuyst, F. 2009. Multilevel assessment of the impact of rain on drivers' behavior. Standartized methodology and empirical analysis, Transportation Research Record 2107: 134-142. http://dx.doi.org/10.3141/2107-14

Bražiūnas, J.; Sivilevičius, H. 2010. The bitumen batching system's modernization and its effective analysis at the asphalt mixing plant, Transport 25(3): 325-335. http://dx.doi.org/10.3846/transport.2010.40

Brown, E. R.; Collins, R.; Brownfield, J. R. 1989. Investigation of segregation of asphalt mixtures in the state of Georgia, Transportation Research Record 1217: 1-8.

Caliendo, C. 2012. Local calibration and implementation of the Mechanistic-Empirical Pavement Design Guide for flexible pavement design, Journal of Transportation Engineering ASCE 138(3): 348-360. http://dx.doi.org/10.1061/(ASCE)TE.1943-5436.0000328

Capuruco, R. A. C.; Hegazy, T.; Tighe, S. L.; Zaghloul, S. 2005. Full-car roughness index as summary roughness statistic, Transportation Research Record 1905: 148156. http://dx.doi.org/10.3141/1905-17

Ceylan, H.; Schwartz, C. W.; Kim, S.; Gopalakrishnan, K. 2009. Accuracy of predictive models for dynamic modulus of hot-mix asphalt, Journal of Materials in Civil Engineering ASCE 21(6): 286-293. http://dx.doi.org/10.1061/(ASCE)0899-1561(2009)21:6 (286)

Chandra, S. 2004. Effect of road roughness on capacity of two-lane roads, Journal of Transportation Engineering ASCE 130(3): 360-364.

http://dx.doi.org/10.1061/(ASCE)0733-947X(2004)130: $3(360)$
Chang, C.-M.; Baladi, G. Y.; Wolff, T. F. 2002. Detecting segregation in bituminous pavements, Transportation Research Record 1813: 77-86. http://dx.doi.org/10.3141/1813-10

Coleri, E.; Tsai, B. W.; Monismith, C. L. 2008. Pavement rutting performance prediction by integrated Weibull approach, Transportation Research Record 2087: 120130. http://dx.doi.org/10.3141/2087-13

Collop, A. C.; McDowell, G. R.; Lee, Y. W. 2006. Modeling dilation in an idealized asphalt mixture using discrete element modeling, Granular Matter 8: 175-184. http://dx.doi.org/10.1007/s10035-006-0013-3

Čygas, D.; Mučinis, D.; Sivilevičius, H.; Abukauskas, N. 2011. Dependence of the recycled asphalt mixture physical and mechanical properties on the grade and amount of rejuvenating bitumen, The Baltic Journal of Road and Bridge Engineering 6(2): 124-134. http://dx.doi.org/10.3846/bjrbe.2011.17

Dawson, A. R. 2008. Rut accumulation and power low models for low-volume pavements under mixed traffic, Transportation Research Record 2068: 78-86. http://dx.doi.org/10.3141/2068-09

de Freitas, E. F.; Pereira, P.; Picado-Santos, L.; Papagiarnakis, A. T. 2005. Effect of construction quality, temperature, and rutting on initiation of top-down cracking, Transportation Research Record 1929: 174182. http://dx.doi.org/10.3141/1929-21

Elsenaar, P. M. W.; van de Fliert, C. 1977. Quality criteria for maintenance and reinforcement of pavements in the Netherlands, Transportation Research Record 652: 65-70.

Fwa, T. F.; Pasindu, H. R.; Ong, G. P. 2012. Critical rut depth for pavement maintenance based on vehicle skidding and hydroplaning consideration, Journal of Transportation Engineering ASCE 138(4): 423-430. http://dx.doi.org/10.1061/(ASCE)TE.1943-5436.0000336

Getautis, E.; Sivilevičius, H. 2009. Lietuvos valstybinès reikšmès keliu asfalto dangos provėžu gylio statistinis tyrimas ir vertinimas [Statistical analysis and evaluation of the depth of the ruts on Lithuanian state significance roads], Mokslas - Lietuvos ateitis [Science future of Lithuania] 1(6): 14-19. http://dx.doi.org/10.3846/mla.2009.6.03

Goh, S. W.; You, Z.; Williams, R. C.; Li, X. 2011. Preliminary dynamic modulus criteria of HMA for field rutting of asphalt pavements: Michigan's experience, Journal of Transportation Engineering ASCE 137(1): 37-45. http://dx.doi.org/10.1061/(ASCE)TE.1943-5436.0000191

Gokhale, S.; Choubane, B.; Byron, T.; Tia, M. 2005. Rut initiation mechanisms in asphalt mixtures as generated under accelerated pavement testing, Transportation Research Record 1940: 136-145. http://dx.doi.org/10.3141/1940-15

Gopalakrishnan, K. 2008. Predicting capacities of runways serving new large aircraft, Transport 23(1): 44-50. http://dx.doi.org/10.3846/1648-4142.2008.23.44-50

Hajj, E.Y.; Morian, N.; El Tannoury, G. A.; Manoharan, S.; Sebaaly, P. E. 2011b. Impact of lime application method on ravelling and moisture sensitivity in HMA mixtures, International Journal of Pavement Engineering 12(2): 149-160. http://dx.doi.org/10.1080/10298436.2010.535539 
Hajj, E. Y.; Tannoury, G.; Sebaaly, P. E. 2011a. Evaluation of rut resistance asphalt mixtures for intersection, Road Materials and Pavement Design 12(2): 263-292. http://dx.doi.org/10.1080/14680629.2011.9695246

Haritonovs, V.; Smirnovs, J.; Naudžuns, J. 2010. Prediction of rutting formation in asphalt concrete pavement, The Baltic Journal of Road and Bridge Engineering 5(1): 38-42. http://dx.doi.org/10.3846/bjrbe.2010.05

Haryanto, I.; Takahashi, O. 2007. Use of secant shear modulus for rutting potential assessment of Indonesian wearing course mixtures, The Baltic Journal of Road and Bridge Engineering 2(3): 95-100.

Hu, S.; Zhou, F.; Scullion, T. 2011. Development, calibration, and validation of new M-E rutting model for HMA overlay design and analysis, Journal of Materials in Civil Engineering ASCE 23(2): 89-99. http://dx.doi.org/http://dx.doi.org/10.1061/(ASCE)MT. 1943-5533.0000130

Kannemeyer, L. 2003. Modelling rutting in flexible pavaments in HDM-4 [online], [cited 12 May 2013], Available from Internet:

http://www.lpcb.org/index.php/component/docman/doc view/459-1995-rut-depth-modelling-rut-depths-in-flex ible-pavements? Itemid $=$

Khedr, A. S.; Breakah, T. M. 2011. Rutting parameters for asphalt concrete for different aggregate structures, International Journal of Pavement Engineering 12(1): 13-23. http://dx.doi.org/10.1080/10298430903578960

Lin, Q.; Cao, D. 2009. Research on material composition and performance of porous asphalt pavement, Journal of Materials in Civil Engineering ASCE 21(4): 135-140.

http://dx.doi.org/10.1061/(ASCE)0899-1561(2009)21:4 (135)

Loizos, A.; Plati, C. 2008. An alternative approach to pavement roughness evaluation, International Journal of Pavement Engineering 9(1): 69-78. http://dx.doi.org/10.1080/10298430600949894

Lottoman, R. P.; Frith, D. J. 1989. Predicting the effects of moisture on wheelpath rutting in asphalt concrete, Transportation Research Record 1228: 63-72.

Malysz, R.; Núñez, W. P.; Bica, A. V. D.; Ceratti, J. A. P.; de Azevédo Bernardes, J. 2012. Investigation of thin pavements rutting based on accelerated pavement testing and repeated loading triaxial tests, Journal of Transportation Engineering ASCE 138(2): 141-148. http://dx.doi.org/10.1061(ASCE)TE.1943-5436.0000298

Markauskas, D.; Kačianauskas, R.; Džiugys, A.; Navakas, R. 2010. Investigation of adequacy of multi-sphere apprimoximation of elliptical particles for DEM simulations, Granular Matter 12: 107-123. http://dx.doi.org/10.1007/s10035-009-0158-y

Mogawer, W. S.; Austerman, A. J.; Daniel, J. S.; Zhou, F.; Bennert, T. 2011. Evaluation of the effects of hot mix asphalt density on mixture fatigue performance, rutting performance and MEPDG distress predictions, International Journal of Pavement Engineering 12(2): 161-175. http://dx.doi.org/10.1080/10298436.2010.546857

Mučinis, D.; Sivilevičius, H.; Oginskas, R. 2009. Factors determining the inhomogeneity of reclaimed asphalt pavement and estimation of its components content variation parameters, The Baltic Journal of Road and Bridge Engineering 4(2): 69-79.

http://dx.doi.org/10.3846/1822-427X.2009.4.69-79

NCHRP. 2004. Guide for the mechanistic-empirical design of new and rehabilitated pavement structures. Report 1 37A. Washington, DC: Transportation Research Board. $93 \mathrm{p}$.

Nukuhya, B.; Roque, R.; Tia, M.; Mehta, Y. A. 2002. Effect of aggregate structure on rutting potential of densegraged asphalt mixtures, Transportation Research Record 1789: 136-145. http://dx.doi.org/10.3141/1789-15

Oscarsson, E. 2011. Evaluation of the mechanistic-empirical pavement design guide model for permanent deformations in asphalt concrete, International Journal of Pavement Engineering 12(1): 1-12. http://dx.doi.org/10.1080/10298430903578952

Perera, R.; Kohn, S. 2004. Effects of variation in quarter-car simulation speed on international roughness index algorithm, Transportation Research Record 1889: 144151. http://dx.doi.org/10.3141/1889-16

Petkevičius, K.; Zilionienè, D.; Vorobjovas, V. 2010. Funkcional conditions and state of hot mix asphalt pavement and its structure of Lithuanian motor roads, The Baltic Journal of Roads and Bridge Engineering 5(1): 43-49. http://dx.doi.org/10.3846/bjrbe.2010.06

Rajbongshi, P.; Das, A. 2008. Optimal asphalt pavement design considering cost and reliability, Journal of Transportation Engineering ASCE 134(6): 255-261. http://dx.doi.org/10.1061/(ASCE)0733-947X(2008)134: $6(255)$

Said, S. F; Oscarsson, E.; Hjort, M. 2011. Prediction of flow rutting in asphalt concrete layers, International Journal of Pavement Engineering 12(6): 519-532. http://dx.doi.org/10.1080/10298436.2011.559549

Salama, H. K.; Haider, S. W.; Chatti, K. 2007. Evaluation of new mechanistic-empirical pavement design guide rutting models for multiple-axle loads, Transportation Research Record 2005: 112-123. http://dx.doi.org/10.3141/2005-13

Shukla, P. K.; Das, A. 2008. A re-visit to the development of fatigue and rutting equations used for asphalt pavement design, International Journal of Pavement Engineering 9(5): 355-364. http://dx.doi.org/10.1080/10298430701690462

Sivilevičius, H. 2011a. Modelling the interaction of transport system elements, Transport 26(1): 20-34. http://dx.doi.org/10.3846/16484142.2011.560366

Sivilevičius, H. 2011b. Application of expert evaluation method to determine the importance of operating asphalt mixing plant quality criteria and rank correlation, The Baltic Journal of Road and Bridge Engineering 6(1): 48-58. http://dx.doi.org/10.3846/bjrbe.2011.07

Sivilevičius, H.; Podvezko, V.; Vakrinienè, S. 2011. The use of constrained and unconstrained optimization modes in gradation design of hot mix asphalt mixture, Construction and Building Materials 25(1): 115-122. http://dx.doi.org/10.1016/j.conbuildmat.2010.06.050

Sivilevičius, H.; Šukevičius, Š. 2007. Dynamics of vehicle loads on the asphalt pavement of European roads which cross Lithuania, The Baltic Journal of Road and Bridge Engineering 2(4): 147-154. 
Sivilevičius, H.; Vislavičius, K. 2008. Stochastic simulation of the influence of variation of mineral material gradin and dose weight on the homogeneity in hot-mix asphalt, Construction and Building Materials 22(9): 2007-2014.

http://dx.doi.org/10.1016/j.conbuildmat.2007.07.001

Solowczuk, A. 2011. Estimation of free-flow speeds on rutted asphalt two-way, two-lane roads with the soft shoulders, The Baltic Journal of Road and Bridge Engineering 6(3): 201-209.

http://dx.doi.org/10.3846/bjrbe.2011.26

Souza, L. T.; Kim, Y.-R.; Souza, F. V.; Castro, L. S. 2012. Experimental testing and finite-element modeling to evaluate the effects of aggregate angularity on bituminous mixture performance, Journal of Materials in Civil Engineering ASCE 24(3): 249-258. http://dx.doi.org/10.1061/(ASCE)MT.1943-5533.0000 386

Taniguchi, S.; Yochida, T. 2003. Calibrating HDM-4 rutting model on national highways in Japan, in The 22nd PIARC World Road Congress, 19-25 October, 2003, Durban, South Africa, $10 \mathrm{p}$.

Thodesen, C. C.; Lerfald, B. O.; Hoff, I. 2012. Review of asphalt pavement evaluation methods and current applications in Norway, The Baltic Journal of Road and Bridge Engineering 7(4): 246-252.

http://dx.doi.org/10.3846/bjrbe.2012.33

Topal, A.; Sengoz, B. 2005. Determination of fine aggregate angularity in relation with the resistance to rutting of hot-mix asphalt, Construction and Building Materials 19(2): 155-163.

http://dx.doi.org/10.1016/j.conbuildmat.2004.05.004

Uddin, M.; Goodrum, P. M.; Mahboub, K. C.; Stromberg, A. 2012. Solution to nonnormality in quality assurance and acceptance quality characteristics data, Transportation Research Record 2268: 50-58. http://dx.doi.org/10.3141/2268-07

Vansauskas, V.; Bogdevičius, M. 2009. Investigation into the stability of driving an automobile on the road pavement with ruts, Transport 24(2): 170-179.

http://dx.doi.org/10.3846/1648-4142.2009.24.170-179

Vasiliev, A. P. 1999. Prichiny obrazovaniia kolei i puti ikh ustraneniia, Nauka i tekhnika $v$ dorozhnoj otrasli 2(9): 6-9.

Wang, H.; Zhang, Q.; Tan, J. 2009. Investigation of layer contributions to asphalt pavement rutting, Journal of Materials in Civil Engineering ASCE 21(4): 181-185. http://dx.doi.org/10.1061/(ASCE)0899-1561(2009)21:4 (181).
Wang, G.; Roque, R.; Morian, D. 2012. Effects of surface rutting on near-surface pavement responses based on a two-dimensional axle-tire-pavement interaction finiteelement model, Journal of Materials in Civil Engineering ASCE 24(11): 1388-1395.

http://dx.doi.org/10.1061/(ASCE)MT.1943-5533.0000526

Xia, K. 2010. A finite element model for tire/pavement interaction: application to predicting pavement damage, International Journal of Pavement Research and Technology 3(3): 135-141.

Xia, K.; Wang, L. 2010. Polishing mechanism and its numerical modeling for flexible pavement, International Journal of Pavement Research and Technology 3(1): 43-50.

Yang, J.; Lu, H.; Zhu, H. 2009. Approaches to rut depth prediction in semirigid asphalt pavements, Journal of Engineering Mechanics ASCE 135(6): 510-516. http://dx.doi.org/10.1061/(ASCE)0733-9399(2009)135: 6(510)

Yavuzturk, C.; Ksaibati, K.; Chiasson, A. D. 2005. Assessment of temperature fluctuations in asphalt pavements due to thermal environmental conditions using a twodimensional, transient finite-difference approach, Journal of Materials in Civil Engineering 17(4): 465-475.

Zaabar, I.; Chatti, K. 2011. New mechanistic-empirical approach for estimating the effect of roughness on vehicle durability, Transportation Research Record 2227: 180-188. http://dx.doi.org/10.3141/2227-20.

Zaghloul, S.; Holland, J. T. 2008. Comparative analysis of long-term field performance of recycled asphalt in California environmental zones, Transportation Research Record 2084: 83-99. http://dx.doi.org/10.3141/2084-10

Zavadskas, E. K.; Turskis, Z. 2011. Multiple criteria decision making (MCDM) methods in economics: an overview, Technological and Economic Development of Economy 17(2): 397-427. http://dx.doi.org/10.3846/20294913.2011.593291

Zavadskas, E. K.; Turskis, Z.; Tamošaitienè, J. 2010. Risk assessment of construction projects, Journal of Civil Engineering and Management 16(1): 33-46. http://dx.doi.org/10.3846/jcem.2010.03

Zhang, J.; Cooley, L. A.; Kandhal, P. S. 2002. Comparison of fundamental and simulative test methods for evaluating permanent deformation of hot-mix asphalt, Transportation Research Record 1789: 91-100. http://dx.doi.org/10.3141/1789-10

Henrikas SIVILEVIČIUS. Prof Dr Habil at the Department of Transport Technological Equipment, Faculty of Transport Engineering, Vilnius Gediminas Technical University, Lithuania. $\mathrm{PhD}$ in the construction of automobile roads (1984). DrSc (2003) in civil engineering. Research interests: hot mix asphalt (HMA) production quality and development of the quality control method, stochastic modelling and the application of statistical methods on the roads of flexible pavement construction, improvement in asphalt recycling technology, multi-criteria decision making (MCDM) in the transport system.

Vidmantas VANSAUSKAS. PhD student at the Department of Transport Technological Equipment, Faculty of Transport Engineering, Vilnius Gediminas Technical University, Lithuania. MSc in transport engineering (2007). Research interests: vehicle dynamics, evaluation of pavement surface condition, modelling road roughness. 